\title{
Compliance, adherence, or implementation?
}

\author{
Gabriel Gulis ${ }^{1}$
}

Received: 22 January 2019/ Accepted: 28 January 2019/Published online: 10 February 2019

(C) Swiss School of Public Health (SSPH+) 2019

Late summer and fall of 1996, I was lucky enough to spend as a Fogarty fellow at University of Iowa, Iowa City, Iowa, USA. I was in the fifth year of my public health career, after spending 8 years in nuclear waste research and short 2 years in civil service as head of a new environmental protection office. During my career, but also in daily life in former Czechoslovakia and later in Slovakia, I often met with regulations, laws, and rules as we used to have plenty of them. However, I also learned, it was a kind of a cultural practice to disobey the rules whenever possible. For example, as a new owner of a driver license, I quickly learned from older fellows that seatbelts were a danger to us as; if a car get fire, we have no chance to escape. Therefore, despite a law requested to wear them, one should avoid wearing them while driving. One evening in Iowa City, our lecturer was driving us to our house and he refused to start his car until we put the seatbelts on. I still remember his argument, which was very clear "it is a law and we must comply." That simple...

Recently, on pages of the International Journal of Public Health, we published a paper on compliance with anti-smoking legislation in Russian Federation (Zasimova 2019), and while reading it that old story came to my mind again. The paper shows that about $27 \%$ of smokers in Russia do not comply with indoor ban of smoking. It is neither the aim of this editorial nor my personal interest to evaluate whether the presented compliance is high or low; I would rather express my thanks to authors for doing this kind of research and presenting it to us.

Compliance or adherence research is quite frequent in biomedical research looking mostly at use of medicine,

Gabriel Gulis

ggulis@ health.sdu.dk

1 Unit for Health Promotion Research, University of Southern Denmark, Esbjerg, Denmark following patient treatment standard procedures, etc. In public health research, this theme seems to be a kind of taboo, likely due to a false feeling of blaming the victims for example in case of not following smoking regulations, or physical activity advice, or nutrition guidance. Perhaps, our focus is still too much on individual level; I believe we should go higher level and look at compliance also at structural level such as on international treaties, agreements, and national policies.

On European level, member states of European region of the World Health Organization agreed upon the Health 2020 policy framework at Regional Committee meeting in September 2012. A recent WHO analysis (WHO 2017) has shown that by 2016, 43 member states (out of 53) responded to question about aligning national policies to Health 2020. Among these, about $62 \%$ did it via a comprehensive national policy, about $28 \%$ did it in a form of "other strategy," and the rest is either planning or not planning to alight their national policies with a policy framework agreed upon by them. I leave it to the readers to consider whether this is high or low compliance.

One of the issues often discussed among global public health fora is the "know-do" gap (van den Driessen Mareeuw et al. 2015), and it is often explained by poor implementation. I would like to challenge the readers; do we mean poor implementation or lack of compliance?

In 2019, there are two socio-politically important anniversaries coming up. First, on May $1^{\text {st }}$, the European Union is going to remember 15 years since its largest expansion, and second, in fall of 2019, the World is going to remember 30 years since the fall of the Berlin wall as the symbolic end of the Cold War. Right after the end of the Cold War, public health science discussed the issue of "East-West life expectancy gap" which has developed in Europe during 1970s-1980s. Now, 30 years later, there is one country from among those behind "iron curtain" who closed the gap and reached the level of EU member states before 2004. Yet, all EU members have theoretically the same rules now, the same access to knowledge, methods, and tools largely driven by common market and legislation. 
Could this be another case of lack of compliance with own decisions?

In Iowa, 1996, I learned how easy it is to break the "wall of compliance, adherence, implementation" if one really wants to do so. Do national policies comply with international? Do practice, research, and education comply with policies or the other way around? I would like to invite us, public health researchers, practitioners, and educators to look at these issues with rigorous methodologies and apply the gathered knowledge in an increased quest for key human values such as accountability, transparency, and honesty. I am sure that the International Journal of Public Health will be happy to receive scientific assessments of success and failure stories.

\section{References}

Van den Driessen MF, Vaandrager L, Klerkx L, Naaldenberg J, Koelen M (2015) Beyond bridging the know-do gap: a qualitative study of systemic interaction to foster knowledge exchange in the public health sector in the Netherlands. BMC Public Health 15:922

WHO: On the road to Health 2020 policy targets: monitoring qualitative indicators. An update, 2017, WHO Copenhagen. http://www.euro.who.int/_data/assets/pdf_file/0010/345799/ Quality_Indicators_2017_EN_FINAL_WEB.pdf?ua=1). Accessed 21 Jan 2019

Zasimova L (2019) Analysis of noncompliance with smoke-free legislation in Russia. Int J Public Health. https://doi.org/10.1007/ s00038-018-1198-z 